\title{
Marketed for Export Only
}

National Cancer Institute

\section{Source}

National Cancer Institute. Marketed for Export Only. NCI Thesaurus. Code C73590.

A category specifying that a product is marketed for export only. 